\title{
Structural mitigation measures for flood reduction in urban area: A case study of Ciliwung watershed
}

\author{
Rizki Maulana Fadillah, Hafizh Tsaqib, Aryanti Karlina Nurendyastuti, Miftahul Jannah, and Rian Mantasa Salve \\ Prastica* $^{*}$ \\ Department of Civil Engineering, Universitas Gadjah Mada, Yogyakarta, Indonesia
}

\begin{abstract}
Flooding is an obstacle for water infrastructure which installed in a river system in Ciliwung, West Java, Indonesia. The climate change triggers unpredictable rainfall which occurs in the watershed, therefore the vulnerability of river and other infrastructures are alarming. The rehabilitation and maintenance strategies are needed to make water infrastructures in the river system obtain lower damage. The research aims to simulate the 2-D HEC-RAS modelling of river system and stability. The result produces the water level of the river even in 1000-year discharge flood. Also, the research proposes the earth embankment dam for flood reduction in the watershed. The dam is designed according to the ideal condition. The simulation of HEC-RAS shows that the river experiences flooding in a certain condition. Besides, the research concludes that designed dam could overcome the flooding problem and suitable strategy for water infrastructure maintenance towards flooding impacts. Further investigation towards soil data for designed dam should be further analyzed to obtain better and comprehensive understanding.
\end{abstract}

\section{Introduction}

Ciliwung River watershed is one of 13 watersheds that are in critical condition due to land-use change. The upstream Ciliwung watershed covers an area of around 14,900 hectares located in Bogor Regency and is included in a mountainous area with an elevation of \pm 2000 meters above sea level. In this region, it is generally culled by the swift flow of floods during the rainy season, which causes downstream areas such as Bogor City and DKI Jakarta Province to experience flooding submissions from the upstream of the Ciliwung watershed. This region also has a high slope variation above $45 \%$.

Changes in land use in the upstream Ciliwung watershed occur from the cover of good vegetation to residential areas between 1981 and now. During this time, there has been a change in the use of land use from forests, technical rice fields, and rain-fed rice fields, which has become a residential area of \pm 300 ha. The conversion of the upstream Ciliwung watershed during the 1990 to 1999 period is relatively rapid, marked by an increase in the area of built land by $20.3 \%$. The impact of land-use change on river flow is reflected by an increase in the maximum average daily flow of the Ciliwung River in 1989 - 1999 and a decrease in the average daily minimum flow of the river so that the water balance is disturbed.

Moreover, several problems arise from the flooding hazard. Various water infrastructures are in danger condition because they are attacked by flooding. The strategy to eliminate the level of the flood is needed to maintain the water infrastructures last longer.
According to the mentioned problems, the Ciliwung river experienced several events of flooding in recent years. Hence, the research aims to simulate the capacity of Ciliwung river due to flooding through 2-D HECRAS modelling. The software is widely used to show the hydraulics profile of a river [1-5]. Moreover, the research designs the rehabilitation of water infrastructure because of the flood by reducing it. The reduction strategy involves the design of the proposed earth embankment dam in the river. The research is necessary due to limited theory of maintenance strategy for water infrastructure through flood reduction.

\section{Methods}

\subsection{Flood analysis}

Flood analysis is computed through Nakayasu synthetic unit hydrograph [6], [7]. To estimate the flood discharge that will occur can be done by a runoff model with the method.

\subsection{Hydraulics analysis}

Hydraulics analysis carried out in this channel planning uses the general theory of HEC-RAS program calculation which is used to calculate one-dimensional river flow profiles, both steady flow and unsteady flow. Hydraulics analysis is needed to plan the channel crosssection dimensions.

\footnotetext{
* Corresponding author: rian.mantasa.s.p@ugm.ac.id
} 
HEC-RAS is a package program from USACE (US Army Corps of Engineer). This software has four components of the hydraulics count, namely: a permanent flow profile, a simulation of non-permanent flow, sediment transport, and a calculation of water quality.

HEC-RAS is a software-based assistive program that can integrate graphical user interface features, hydraulic analysis, reporting, graphics and data management and storage. Graphic facilities provided by HEC-RAS include, among other things, cross-section, elongated views.

HEC-RAS is an application program for modelling open channel flows such as drainage, rivers, and other open channel cross-sections. River Analysis System (RAS), created by the Hydrologic Engineering Center (HEC) which is a work unit under the US Army Corps of Engineers (USACE). HEC-RAS can present onedimensional modelling of steady and unsteady onedimensional flow models.

In channel modelling using HEC-RAS, the input of the four components can use the same geometry data and hydraulic calculation routines, as well as several hydraulic design features that can be accessed after the countdown of the water profile. HEC-RAS is an application program that integrates features of the graphical user interface, hydraulic analysis, management and storage of data, graphics, and reporting.

\subsection{Earth embankment dam: water infrastructure rehabilitation strategy}

Landfill dams are dams that are commonly built because the construction uses locally available excavated material that does not need much processing. Compared to other types of dams, this type can be built on almost all types of foundation soil and poor topography.

The design of the dam is supported by the usage of SLOPE/W software. SLOPE/W is a software product for calculating soil safety and rock slope factors. SLOPE/W can be analyzed both simple and complex problems using one of eight boundary equilibrium methods for various sloped surfaces, compressive conditions of water pores, soil properties and concentrated loads. The program is also widely used to simulate stability [7-10].

\section{Results and Discussion}

\subsection{Flood design}

The maximum rainfall intensity data in the research is obtained from three rain gauge station: Halim Perdana Kusuma, Bogor Climatology, and Citeko rain gauge station. To calculate the maximum weighted annual daily rainfall it is necessary to calculate the weight of the catchment area using the Thiessen method [6], [7], [11]. Figure 1 depicts the Thiessen analysis in the research area.

After that, the rainfall data is analyzed through Smirnov-Kolmogorov method. The acceptable group of data then computed by using Nakayasu method. The result of Nakayasu method to analyze the design flood is depicted in Figure 2.

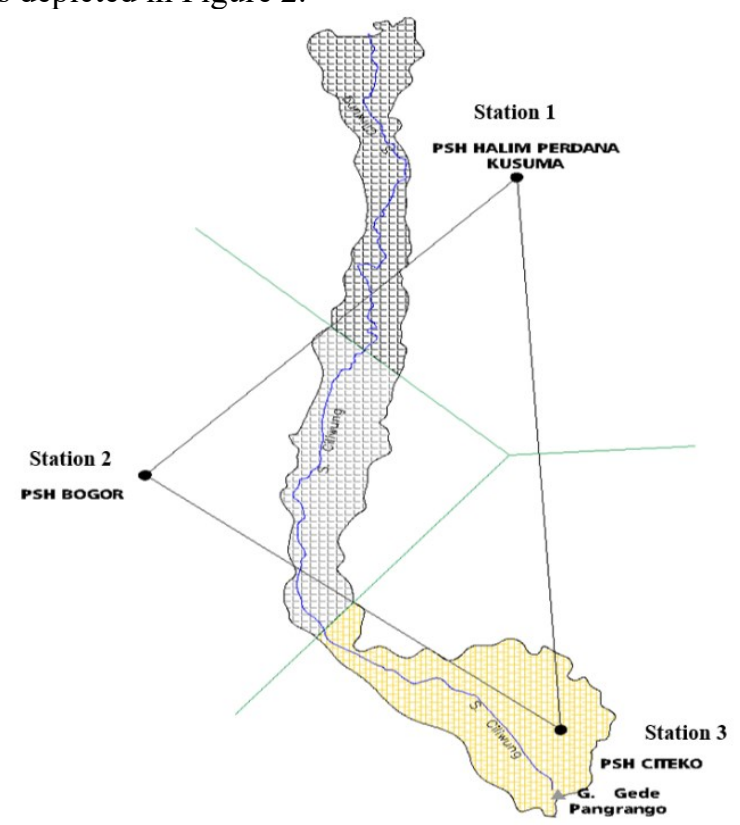

Fig. 1. Ciliwung subwatershed

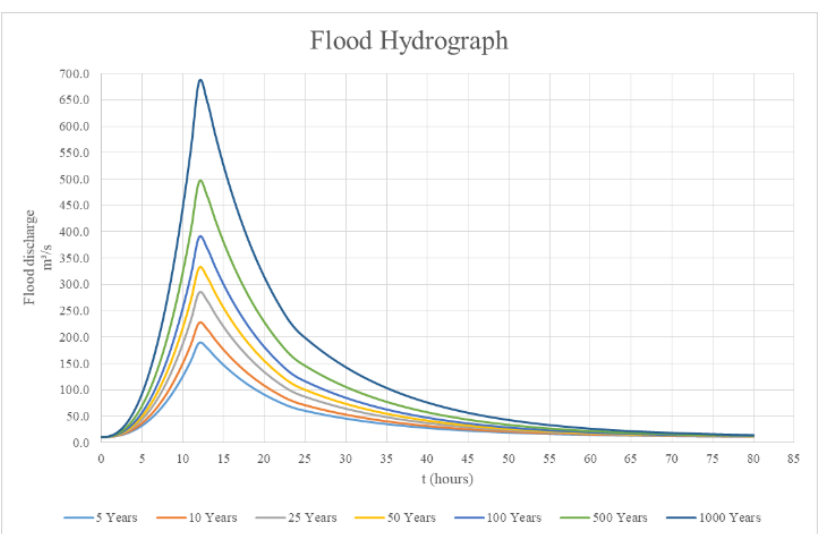

Fig. 2. Flood hydrograph of Ciliwung sub-watershed

\subsection{Hydraulics analysis: HEC-RAS modelling approach}

Hydraulic analysis of the Ciliwung River using HECRAS modelling was carried out to obtain the channel capacity needed to help overcome the problem of flooding in the Upper Ciliwung River area.

The planned discharge amount acts as a boundary condition in modelling at HEC-RAS and is modelled as an inflow or lateral discharge that enters the channel. The next step is to enter the condition of the river flow whether the flow is fixed (steady flow) or the condition of the flow is not fixed (unsteady flow). In this analysis carried out by unsteady flow analysis. Then the hydrograph flow and stage hydrograph values will be entered, where the flow hydrograph values are obtained from the flood discharge calculation of the Nakayasu method plan.

Analysis of the existing cross-sectional capacity of the Ciliwung River is carried out on the current river conditions to find out the maximum drainage capacity in each river segment. 


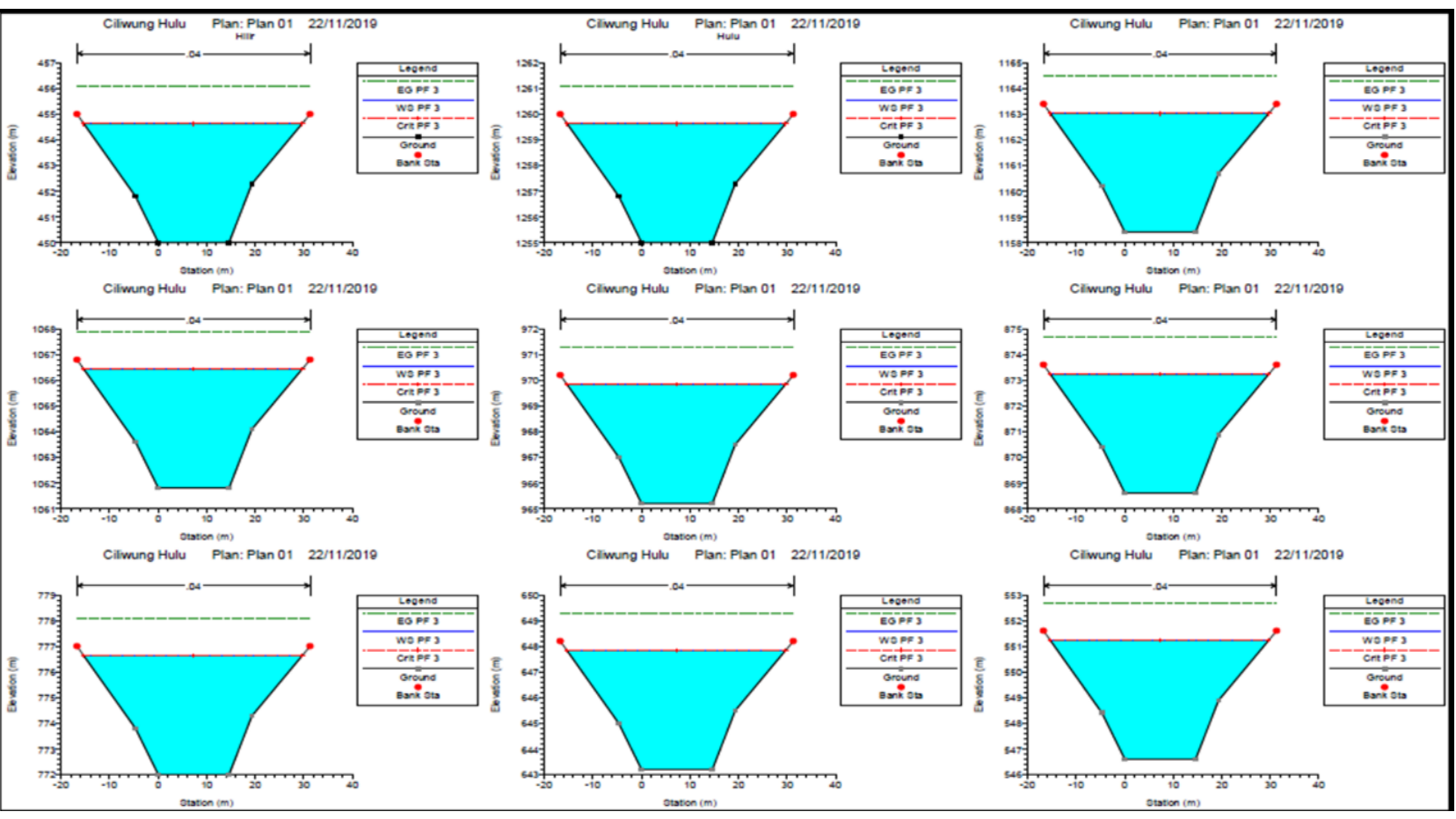

Fig. 3. 2-D HEC-RAS modelling result

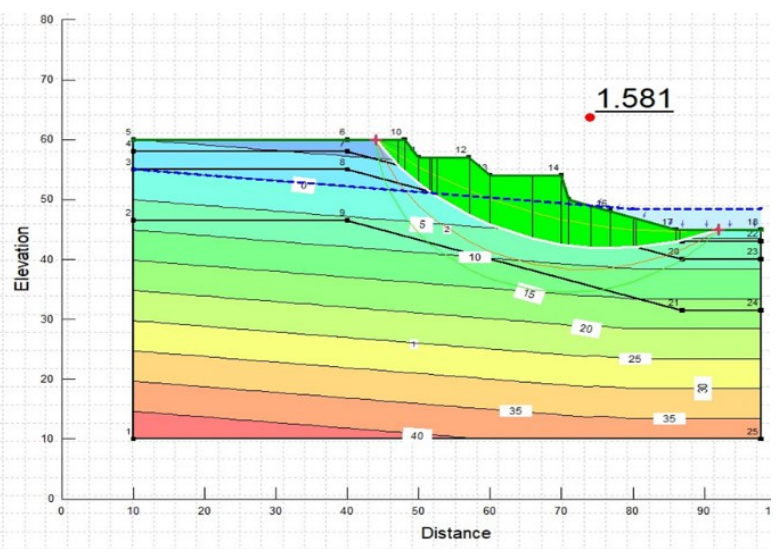

Fig. 4. Slope stability of Upper Ciliwung River

The analysis of HEC-RAS simulation is depicted in Figure 3. The analysis uses a design flood for 1000 years. Besides flood analysis, slope stability strength of the river embankment is analyzed by using Geo-Studio supporting tool. Figure 4 describes the condition of the slope stability of the Ciliwung River

Based on the results of the slope analysis with Geostudio from the existing channels, the slope is qualified as safe condition, because the slope safety factor requirement is approximately between 1.5 and 2 .

\subsection{Earth embankment dam design}

The construction of a proposed dam in the upstream part of the Ciliwung River is needed as an effort to reduce and mitigate flooding in the downstream part of the Ciliwung River. The research aims to design the eligible dam which could be an option to build.

Based on the plan, the dam will be placed in the Megamendung area, Bogor regency, West Java, with +573 meters above sea level. The dam is planned to have an area of 782 hectares with a dam body length of 100 meters. The location was chosen based on several considerations including the availability of land, being in the highlands, blocking some river branches, and not a densely populated area so that if the land acquisition is expected to be more economical.

After the design process, the dimension and the body structure of the dam are analyzed to obtain the safety factor. Figure 5 depicts the result of SLOPE/W analysis.

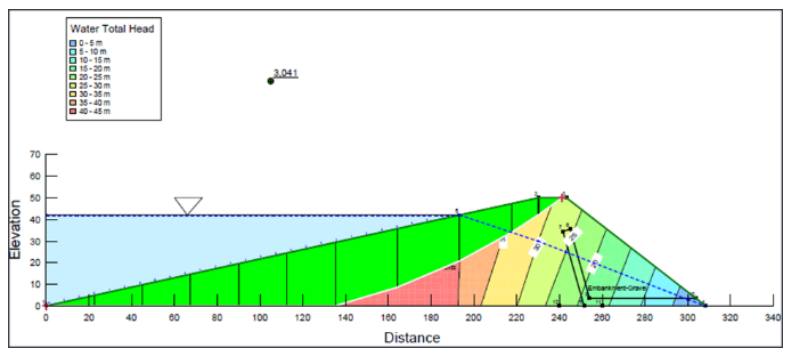

Fig. 5. Slope stability analysis

Analysis of the dam body slope with Geo-Studio software. The results of slope stability analysis on the body of the dam as in Figure 5 shows that the dam classified as safe with a safety factor of 3.041 meets the minimum SF requirement of 1.5. Analysis of dam body seepage with Geo-Studio software with this type also reduces pore water level to the drainage area of the dam so that seepage or seepage does not occur in the above dam. Figure 6 describes the seepage analysis.

The construction of dams in the Ciliwung watershed can be said to be effective in reducing flooding. As seen in numerical analysis and flood routing graphs, planned dams with an area of 752 hectares, dam body length of 100 meters, a height of 50.05 meters can reduce peak flooding to approximately $1100 \mathrm{~m}$. Originally inflow (design flood) reached 2800 now outflow to $1700 \mathrm{~m}^{3} / \mathrm{s}$. 
Figure 7 describes the flood reduction by using the proposed dam.

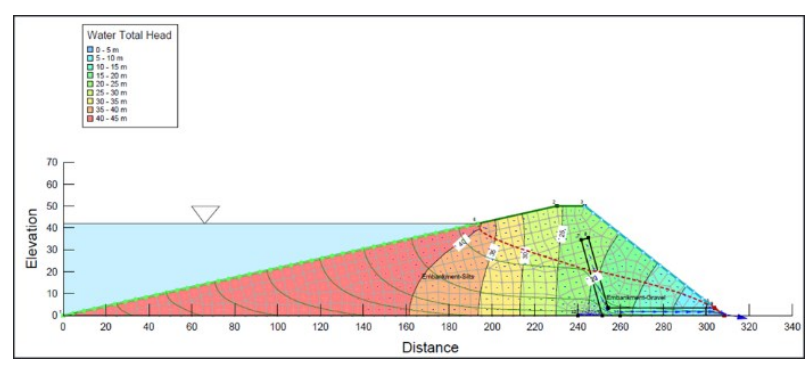

Fig. 6. Seepage analysis

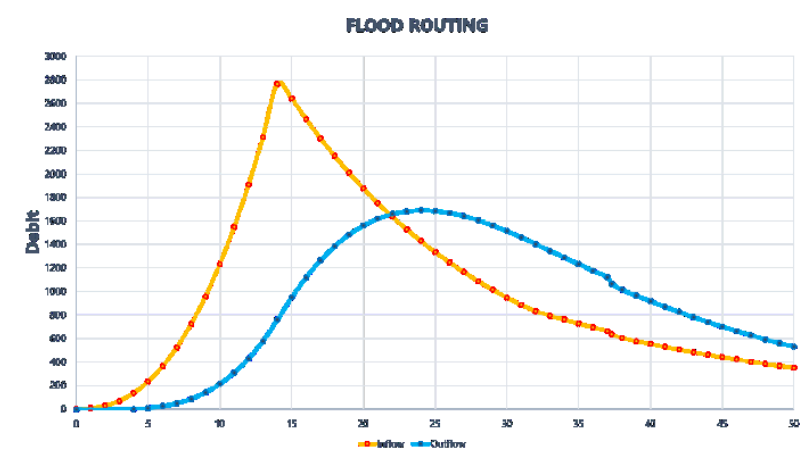

Fig. 7 Flood routing

\section{Conclusion}

The existing Upper part of Ciliwung river channel has more than enough capacity if the flood discharge is planned for the category of channel construction (100year design flood discharge), but if subject to 1000-year flood discharge, the channel status will be alarming due to elevation water is only less than 1 meter with a channel surface threshold to overflow. Construction of a dam with an area of 752 hectares in the Megamendung area, Bogor regency, is considered significant in the effort to reduce flooding as water infrastructure maintenance strategy.

The research is supported by Research Grant of Dana Masyarakat of Vocational College Universitas Gadjah Mada year of 2020. Authors thank the Civil Engineering Department, Vocational College, Universitas Gadjah Mada. Furthermore, the authors would like to deliver gratitude to Hydraulics and Water Infrastructure Laboratory.

\section{References}

[1] R. M. S. Prastica, C. Maitri, P. C. Nugroho, and A. Hermawan, "Analisis Banjir dan Perencanaan Desain Transportasi Sungai di Kota Bojonegoro,"
Media Komun. Tek. Sipil, vol. 23, no. 2, p. 91, 2017. in Bahasa

[2] F. Geravand, S. M. Hosseini, and B. AtaieAshtiani, "Influence of river cross-section data resolution on flood inundation modeling: Case study of Kashkan river basin in western Iran," J. Hydrol., vol. 584, no. December 2019, p. 124743, 2020.

[3] R. M. S. Prastica and D. Wicaksono, "Integrated multimodal disaster mitigation management for urban areas: A preliminary study for 2-d flood modeling," in IOP Conference Series: Materials Science and Engineering, 2019, vol. 650, no. 1.

[4] M. Zeleňáková, R. Fijko, S. Labant, E. Weiss, G. Markovič, and R. Weiss, "Flood risk modelling of the Slatvinec stream in Kružlov village, Slovakia," J. Clean. Prod., vol. 212, pp. 109-118, 2019.

[5] I. Mondal, J. Bandyopadhyay, and A. K. Paul, "Estimation of hydrodynamic pattern change of Ichamati River using HEC RAS model, West Bengal, India," Model. Earth Syst. Environ., vol. 2, no. 3, pp. 1-13, 2016.

[6] R. M. S. Prastica, C. Maitri, A. Hermawan, P. C. Nugroho, D. Sutjiningsih, and E. Anggraheni, "Estimating design flood and HEC-RAS modelling approach for flood analysis in Bojonegoro city," in IOP Conference Series: Materials Science and Engineering, 2018, vol. 316, no. 1.

[7] R. M. S. Prastica, D. A. R. Adi, and N. Famila, "Mitigasi banjir dan alternatif pemeliharaan infrastruktur keairan pada," vol. 16, no. 01, pp. 25-33, 2020.

[8] GEO-SLOPE International Ltd., Stability Modeling with SLOPE / W, July 2012., no. July. Calgary, Alberta, Canada: GEO-SLOPE International Ltd., 2012.

[9] D. G. Shole and M. Z. Belayneh, "The effect of side slope and clay core shape on the stability of embankment dam: Southern Ethiopia," Int. J. Environ. Sci. Technol., vol. 16, no. 10, pp. 58715880, 2019.

[10] S. Yu, X. Ren, J. Zhang, H. Wang, and Z. Zhang, "Sensibility analysis of the hydraulic conductivity anisotropy on seepage and stability of sandy and clayey slope," Water (Switzerland), vol. 12, no. 1, 2020.

[11] A. P. Piotrowski, M. Osuch, and J. J. Napiorkowski, "Joint Optimization of Conceptual Rainfall-Runoff Model Parameters and Weights Attributed to Meteorological Stations," Water Resour. Manag., vol. 33, no. 13, pp. 4509-4524, 2019. 